\title{
Establishment of a new human osteosarcoma cell line, UTOS- I: cytogenetic characterization by array comparative genomic hybridization
}

\author{
Taketoshi Yasuda*1, Masahiko Kanamori ${ }^{1}$, Shigeharu Nogami ${ }^{1}$, \\ Takeshi Hori ${ }^{1}$, Takeshi Oya ${ }^{2}$, Kayo Suzuki ${ }^{1}$ and Tomoatsu Kimura ${ }^{1}$
}

\author{
Address: ${ }^{1}$ Department of Orthopaedic Surgery, Faculty of Medicine, University of Toyama, 2630 Sugitani, Toyama 930-0194, Japan and \\ ${ }^{2}$ Department of 2nd Pathology, Faculty of Medicine, University of Toyama, 2630 Sugitani, Toyama 930-0194, Japan \\ Email: Taketoshi Yasuda* - yasuda@med.u-toyama.ac.jp; Masahiko Kanamori - kanamori@med.u-toyama.ac.jp; \\ Shigeharu Nogami - Nogami@med.u-toyama.ac.jp; Takeshi Hori - takhori@med.u-toyama.ac.jp; Takeshi Oya - oya@med.u-toyama.ac.jp; \\ Kayo Suzuki - suzukayo@med.u-toyama.ac.jp; Tomoatsu Kimura - tkimura@med.u-toyama.ac.jp \\ * Corresponding author
}

Published: 25 February 2009

Journal of Experimental \& Clinical Cancer Research 2009, 28:26 doi:10.1 I86/1756-9966-28-26
Received: 7 January 2009

Accepted: 25 February 2009

This article is available from: http://www.jeccr.com/content/28/I/26

(c) 2009 Yasuda et al; licensee BioMed Central Ltd.

This is an Open Access article distributed under the terms of the Creative Commons Attribution License (http://creativecommons.org/licenses/by/2.0), which permits unrestricted use, distribution, and reproduction in any medium, provided the original work is properly cited.

\begin{abstract}
The cytogenetic characteristics of osteosarcoma (OS) remain controversial. The establishment of a new human OS cell line may improve the characterization. We report the establishment of a new human osteosarcoma cell line, UTOS-I, from a typical osteoblastic OS of an I8-year-old man. Cultured UTOS-I cells are spindle-shaped, and have been maintained in vitro for over 50 passages in more than 2 years. Xenografted UTOS-I cells exhibit features typical of OS, such as production of osteoid or immature bone matrix, and proliferation potency in vivo. UTOS-I also exhibit morphological and immunohistochemical characteristics typical of osteoblastic OS. Chromosomal analysis by G-band show 73 85 chromosomes with complicated translocations. Array CGH show frequent gains at locus DAB2 at chromosome 5q13, CCND2 at I2pI3, MDM2 at I2qI4.3-qI5, FLI and TOP3A at I7pII.2-p/2 and OCRLI at Xq25, and show frequent losses at HTRIB at $6 q 13$, D6S268 at 6qI6.3-q2I, SHGCI7327 at I8ptel, and STK6 at 20qI3.2-qI3.3. The UTOS-I cell line may prove useful for biologic and molecular pathogenetic investigations of human OS.
\end{abstract}

\section{Introduction}

Osteosarcoma (OS) is the most common malignant bone tumor in adolescents and young adults, and is characterized by proliferation of tumor cells which produce osteoid or immature bone matrix. Despite recent advances in multimodality treatment consisting of aggressive adjuvant chemotherapy and wide local excision, pulmonary metastasis occurs in approximately 40 to $50 \%$ of patients with OS and remains a major cause of fatal outcome [1-3].
There have been several reports describing xenotransplantation models of human OS [4-7], but characterization of human OS at the molecular cytogenetic level has been limited $[8,9]$. We describe the establishment and characterization of a new human OS cell line, designated as UTOS-1, derived from a conventional osteoblastic OS. In addition, we analyze chromosomal aberrations and DNA copy number changes in UTOS-1 by array comparative genomic hybridization $(\mathrm{aCGH})$. 


\section{Methods \\ Source of Tumor Cells}

An 18-year-old Japanese man noticed swelling and pain of the left shoulder for 2 months. Radiographs showed a periosteal reaction and an osteosclerotic change in the proximal metaphysis of the left humerus. An open biopsy of this humeral tumor confirmed that it was conventional osteoblastic OS (Figure 1). Immunohistochemically, most of the tumor cells were strongly positive for vimentin, alkaline phosphatase (ALP), osteopontin (OP), and osteocalcin (OC). Despite intensive chemotherapy, the patient died of lung metastasis 2 months after open biopsy. The present study was conducted after a human experimentation review by our ethics committee.

\section{Tumorigenicity in severe combined immunodeficiency (SCID) mice}

To determine the tumorigenicity of the UTOS-1 cell line in vivo, $1 \times 10^{8}$ cells were washed, suspended in phosphatebuffered saline (PBS), and injected subcutaneously into the leg of 4-week-old male SCID mice (CB-17/Icrscid; Clea Japan Incorporation, Osaka, Japan). Also, tumor growth in vivo was measured by calculating tumor volume based on the measurement of 2 perpendicular diameters using a caliper [10]. The volume was estimated using the following formula: $0.5 \times \mathrm{L} \times(\mathrm{S})^{2}$, where $\mathrm{L}$ and $\mathrm{S}$ are the largest and smallest perpendicular tumor diameters, respectively.

\section{Establishment of the tumor cell line}

Tumor cells were seeded in a $25 \mathrm{~cm}^{2}$ plastic flask (353109; Falcon, Franklin Lakes, NJ, USA) [11]. These cells were cultured in RPMI 1640 (MP Biomedicals, Solon, OH, USA), supplemented with $100 \mathrm{mg} / \mathrm{ml}$ streptomycin (Meiji

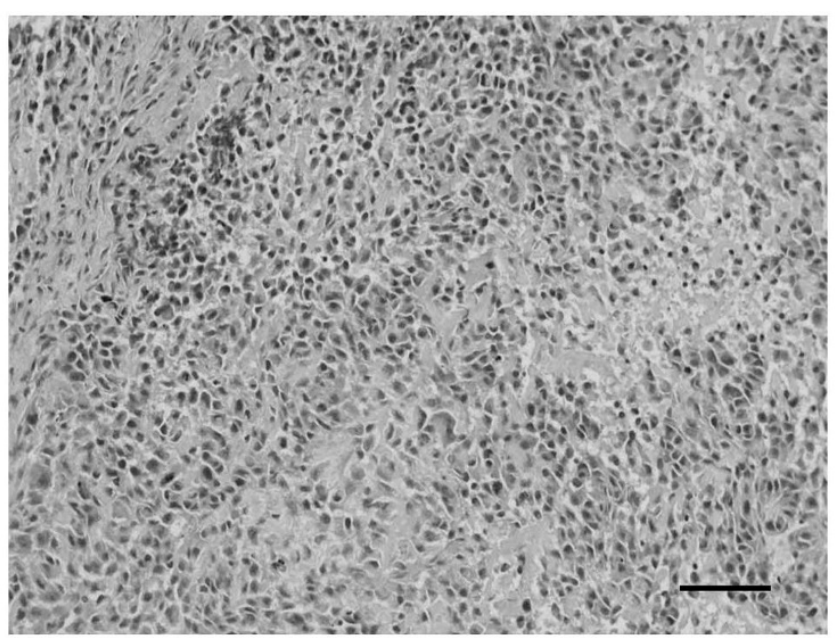

\section{Figure I}

Histologic appearance of the original tumor. Spindleshaped tumor cells with atypical nuclei have proliferated with formation of osteoid or immature bone matrix (H\&E stain). Sclae bar: $100 \mu \mathrm{m}$.
Seika, Tokyo, Japan), $100 \mathrm{U} / \mathrm{ml}$ penicillin (Meiji Seika) and $10 \%$ fetal bovine serum (FBS; Funakoshi, Tokyo, Japan), at $37^{\circ} \mathrm{C}$ in a humidified atmosphere of $5 \% \mathrm{CO}_{2}$ and $95 \%$ air. The medium was replaced once per week. When semiconfluent layers were obtained, the cells were dispersed with $\mathrm{Ca}^{2+}$ - and $\mathrm{Mg}^{2+}$-free PBS containing $0.1 \%$ trypsin and $0.02 \%$ EDTA solution, and were then seeded in new flasks for passage. The configuration of tumor cells was almost equalized after the 3rd generation. These procedures were serially performed until the UTOS-1 cell line was established.

\section{Cell growth in vitro}

To determine the doubling time, UTOS-1 cells were seeded in each well of 96-well dishes (Corning Costar, Tokyo, Japan) with fresh medium containing $100 \mu \mathrm{l}$ of RPMI 1640 with 10\% FBS. Cell growth was measured using the 3-(4,5-dimethylthiazol-2-yl)-2,5-diphenyltetrazolium bromide (MTT) assay (Cell Counting Kit-8, Dojindo, Tokyo, Japan) [12]. A volume of $10 \mu \mathrm{l}$ of MTT was added to each well, followed by mixing. Plates were incubated for 3 hours at $37^{\circ} \mathrm{C}$ in a humidified atmosphere of $5 \% \mathrm{CO}_{2}$ and $95 \%$ air. Formazan levels, which correspond to the number of viable cells, were quantified using a microplate reader (model 450; Bio-Rad Laboratories, Hercules, CA, USA) at a wavelength of $450 \mathrm{~nm}$. The absorbance of each well was evaluated at 6, 12, 24, 48, 72, 96 and 120 hours after seeding. Triplicate wells were used for each observation.

\section{Immunohistochemistry}

Cells were cultured in chamber slides (Lab-Tek; Nalge Nunc International, Naperville, IL, USA). For the detection of mesenchymal phenotype, we used 3 monoclonal antibodies: anti-AE1/AE3, anti-keratin mix, and antivimentin. Also, to assess osteoblastic differentiation, we used 2 monoclonal antibodies: anti-OP and anti-OC. ALP activity of UTOS-1 cells was estimated using a modified version of a cytochemical method described elsewhere [13], with naphthol AS-MX phosphate-fast blue RR staining (ALP staining kit; Muto Pure Chemicals Corporation, Tokyo, Japan).

Cells grown in chamber slides were washed in PBS, fixed in 4\% paraformaldehyde for 15 minutes at room temperature, and then fixed in methanol for 20 minutes at $20^{\circ} \mathrm{C}$. The cells were incubated with each of the primary antibodies for 24 hours at $4^{\circ} \mathrm{C}$. Immunoreaction products were detected using DAKO envision (DAKO Sytomation, Carpinteria, CA, USA), and were visualized after adding diaminobenzidine (DAB; DAKO) as the chromogen.

\section{RNA extraction and reverse-transcription polymerase chain reaction (RT-PCR)}

Expression of osteoblastic differentiation markers was assessed using RT-PCR. UTOS-1 cells were grown to con- 
fluence, and total cellular RNA was isolated using a TRIzol $^{\circledast}$ Reagent (Invitrogen, San Diego, CA, USA). Total RNA was used as a template for cDNA synthesis using the SuperScript First-strand Synthesis System (Invitrogen). PCR was performed to assess expression of ALP, OP and OC. The oligonucleotide primer sequences and PCR conditions for ALP, OP and OC are shown in Table 1. Amplified products were analyzed by $2 \%$ agarose gel (Cambrex Bio Science Rockland Incorporation, Rockland, ME, USA) electrophoresis and ethidium bromide staining (Invitrogen). For comparison, Saos-2 [7], which is one of the most popular OS cell lines, was used as a positive control.

\section{Cytogenetic analysis}

For cytogenetic analysis, preparations of metaphase chromosomes from UTOS- 1 cells at passage 15 were obtained, and were banded with Giemsa-trypsin [14]. Karyotypes were described using the short version of the International System for Human Cytogenetic Nomenclature [15].

\section{DNA extraction and array $\mathbf{C G H}$}

Genomic DNA was extracted from UTOS-1 cells at passage 15. The CGH procedure used was similar to published standard protocols [16]. Genomic DNA was isolated from tumor samples using standard procedures including proteinase K digestion and phenol-chloroform extraction.

Array CGH was performed using the GenoSensor Array 300 system, following the manufacturer's instructions (Vysis, Downers Grove, IL, USA). This array contains the 287 chromosomal regions that are commonly altered in human cancer, such as telomeres, regions involved in microdeletions, oncogenes, and tumor suppressor genes. Tumor DNA (100 ng) was labeled by random priming with fluorolink cy3-dUTP, and normal reference (control) DNA was labeled using the same method with cy5-dUTP. The tumor and control DNAs were then mixed with Cot1 DNA (GIBCO-BRL, Gaithersburg, MD, USA), precipitated, and resuspended in microarray hybridization buffer containing $50 \%$ formamide. The hybridization solution was heated to $80^{\circ} \mathrm{C}$ for 10 minutes to denature the DNA, and was then incubated for 1 hour at $37^{\circ} \mathrm{C}$. Hybridization was performed for 72 hours in a moist chamber, followed by a post-hybridization wash in $50 \%$ formamide $/ 2 \times$ SCC at $45^{\circ} \mathrm{C}$. Slides were mounted in phosphate buffer containing 4',6-diamidino-2-phenylindole (DAPI; Sigma, St. Louis, MO, USA). Fluorescence intensity images were obtained using the GenoSensor Reader System (Vysis) according to the manufacturer's instructions. For each spot, the total intensity of each of the 2 dyes and the ratio of their intensities were automatically calculated. The diagnostic cut-off levels representing gains and losses were set at 1.2 (upper threshold) and 0.8 (lower threshold). This assay was performed in triplicate, and common aberrations were considered to be meaningful aberrations.

\section{Results}

\section{Tumor growth in vivo}

Approximately 5 weeks after implantation, all SCID mice had palpable elastic hard nodules with a volume of about $1000 \mathrm{~mm}^{3}$ (Figure 2). The tumor volume was about 4000 $\mathrm{mm}^{3}$ at 6 weeks after implantation, and was $>10,000$ $\mathrm{mm}^{3}$ at 8 weeks after implantation. The cut surfaces of these tumors were solid and white-gray with small necrotic foci. Histopathologically, the tumors contained primarily atypical tumor cells, and exhibited formation of osteoid or immature bone matrix, which is similar in characteristics to the original tumor (Figure 3).

\section{Cell growth and morphological findings in vitro}

UTOS-1 cells were spindle-shaped, contained several nucleoli, and formed clumps. Two weeks after initial cultivation in primary culture, the tumor cells reached subconfluence with some piled-up foci of cells (Figure 4A). After the cells were serially subcultured for about 3 months, they began to grow rapidly at passage 6 (Figure 4B).

This new cell line has been maintained in vitro for more than 50 passages over more than 2 years. In the exponential phase of cell growth, the population-doubling time was 40 hours (Figure 5).

Table I: The oligonucleotide primer sequences and PCR conditions for ALP, OP, and OC in this study.

\begin{tabular}{|c|c|c|c|c|}
\hline Molecule & $\begin{array}{l}\text { Primers } \\
\left.\text { (5' to } 3^{\prime}\right)\end{array}$ & Strand & Size (bp) & $\begin{array}{c}\text { Conditions } \\
\text { (temperature, cycle number) }\end{array}$ \\
\hline ALP & $\begin{array}{l}\text { ACGTGGCTAAGAATGTCATC } \\
\text { CTGGTAGGCGATGTCCTTA }\end{array}$ & + & 475 & $\begin{array}{c}55^{\circ} \mathrm{C} \\
35 \text { cycles }\end{array}$ \\
\hline OP & $\begin{array}{c}\text { CCAAGTAAGTCCAACGAAAG } \\
\text { GGTGATGTCCTCGTCTGTA }\end{array}$ & + & 347 & $\begin{array}{c}58^{\circ} \mathrm{C} \\
45 \text { cycles }\end{array}$ \\
\hline OC & $\begin{array}{l}\text { ATGAGAGCCCTCACACTCCTC } \\
\text { GCCGTAGAAGCGCCGATAGGC }\end{array}$ & $\begin{array}{l}+ \\
--\end{array}$ & 294 & $\begin{array}{c}59^{\circ} \mathrm{C} \\
45 \text { cycles }\end{array}$ \\
\hline GAPDH & $\begin{array}{l}\text { GAAGGTGAAGGTCGGAGTCA } \\
\text { GAAGATGGTGATGGGATTTC }\end{array}$ & + & 226 & $\begin{array}{l}55^{\circ} \mathrm{C} \\
35 \text { cycle }\end{array}$ \\
\hline
\end{tabular}

Abbreviations: ALP, alkaline phosphatase; OP, osteopontin; OC, osteocalcin; GAPDH, glyceraldehyde-3-phosphate dehydrogenase. 


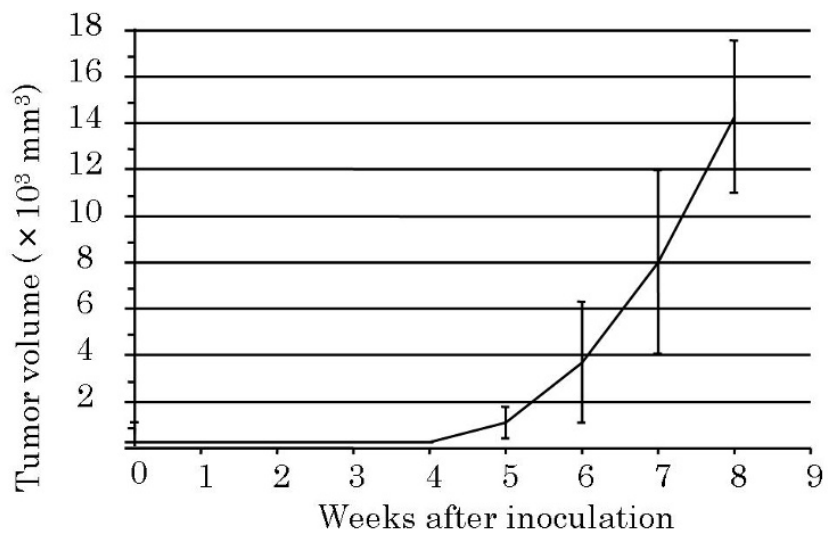

\section{Figure 2}

Tumor volume in SCID mice. Tumor volume in logarithmic growth phase, $\sim 5$ weeks after inoculation. Values are expressed as the mean \pm standard deviation of triplicate cultures.

\section{Immunohistochemical and cytochemical findings}

All UTOS-1 cells were negative for AE1/AE3 and keratin mix. Most UTOS-1 cells were positive for vimentin. All UTOS-1 cells were positive for OP, OC and ALP (Figure $6)$.

\section{RT-PCR}

UTOS-1 cells expressed ALP, OP and OC, which is similar to the results for Saos-2 (Figure 7).

\section{Cytogenetic findings}

A representative karyotype is shown in Figure 8. 50 UTOS1 cells exhibited a complex karyotype. The karyotypes of UTOS-1 cells at passage 15 were similar to those of the original tumor. The composite karyotypes were as follows:
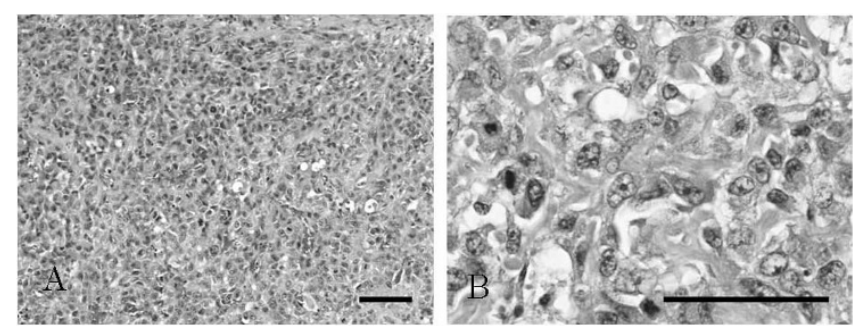

Figure 3

Histologic appearance of xenografted tumor in SCID mice. A. Xenografted tumor showing features typical of osteoblastic osteosarcoma with atypical spindle-shaped cells (H\&E stain). Scale bar: $100 \mu \mathrm{m}$. B. The proliferation of atypical tumor cells with osteoid formation is shown. Xenografted tumor cells resemble original tumor cells. Scale bar: $50 \mu \mathrm{m}$.
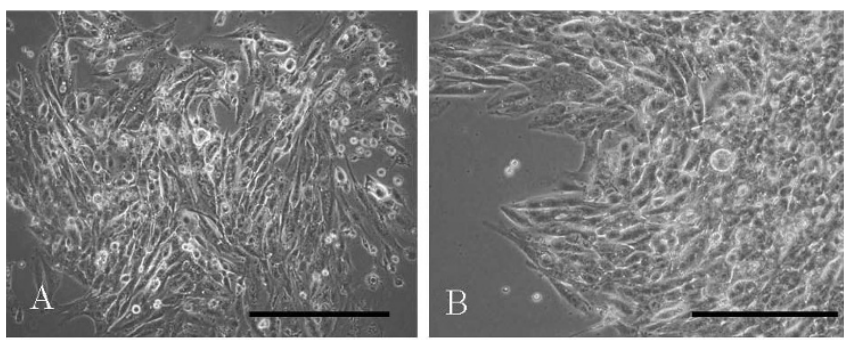

\section{Figure 4}

Morphology under phase-contrast microscopy. A. In primary culture, spindle-shaped tumor cells reach subconfluence with some piled-up foci of cells. Scale bar: $100 \mu \mathrm{m}$. B.

At passage 6, the tumor cells begin to grow rapidly. The configuration of tumor cells is equalized after the 6th generation. Scale bar: $100 \mu \mathrm{m}$.

73 85, Y, -X [7],+Y[10], $\operatorname{add}(\mathrm{X})(\mathrm{q} 11)[9], \operatorname{add}(\mathrm{X})(\mathrm{q} 11)$ [2],+1[8], del(1)(q11)[9], $\quad \operatorname{der}(1) \operatorname{add}(1)(\mathrm{p} 11) \operatorname{add}(1)$ (q42)[9], der(1) add(1)(p22)add(1)(q32)[2], der(1)add(1 )(p32)add(1)(q42)[6],-3[10],-4[3], add(4)(q11)[9],-5

[4], $\operatorname{del}(5)(\mathrm{p} 13)[9], \quad+\operatorname{add}(6)(\mathrm{q} 11)[3], \operatorname{der}(6) \operatorname{del}(6)(\mathrm{p} 21)$ $\operatorname{add}(6)(\mathrm{q} 2 ?)[10], \operatorname{der}(6) \operatorname{del}(6)(\mathrm{p} 24) \operatorname{add}(6)(\mathrm{q} 13) \times 2,[10]-$ 7[10], add(7)(p22)[6],der(7)t(7;7)(p22;q22)[10],+8[3],-$9[10],-9[8], \operatorname{add}(9)(\mathrm{q} 22)[9],-10[10], \operatorname{add}(10)(\mathrm{p} 11)[4]$, add (10)(q26)[7], der(10)add(10)(p11)add(10)(q26)[3], add (11)(p11)[9], add(11)(p11)[4], $\operatorname{del}(11)(\mathrm{p} 11)[6],-12[5]$, $\operatorname{der}(12)(\mathrm{q} 21)[6], \operatorname{der}(12) \operatorname{add}(12)(\mathrm{p} 11) \operatorname{add}(12)(\mathrm{q} 24)[10]$ , der(12)add(12)add(12)[7],-13[10],+14[2], add (14) (p11)[10], add(14)[2], add(14)(p11)[8],-15[7], add (15)(p11)[5], add(15)(p11)[4],+16[5], add(16)(p11)[3],

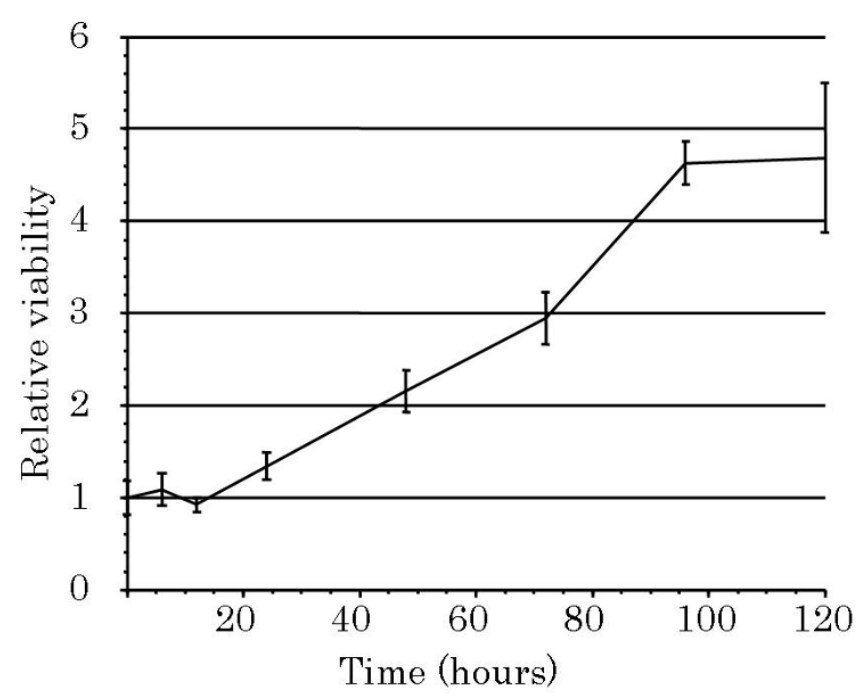

Figure 5

Tumor cell growth in vitro. UTOS-I cells begin to grow $\sim 24$ hours after inoculation. The population-doubling time of the cells is 40 hours. Values are expressed as the mean \pm standard deviation of triplicate cultures. 

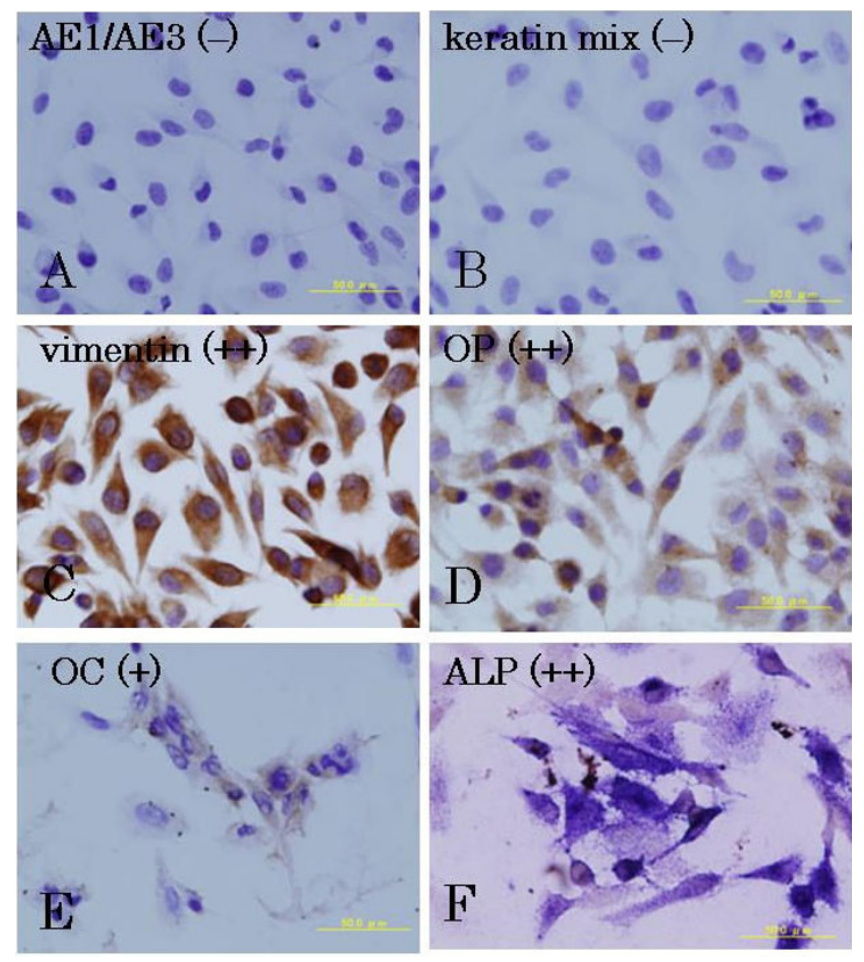

Figure 6

Immunohistochemical findings. A, B. UTOS-I cells are negative for AEI/AE3 and keratin mix. C, D, E. Most UTOSI cells are positive for vimentin, OP, and OC. F. Staining for ALP was performed using a modified cytochemical method. ALP activity is visible as blue staining. UTOS-I cells are strongly positive for ALP.

$\operatorname{add}(16)(\mathrm{q} 24)[2], \operatorname{add}(16)(\mathrm{p} 11)[10], \operatorname{add}(16)[4],-17[10],-$ 17[8],add(17)(q24)[3],?del(17)(p11)[3],-18[5],add(18) (p11)[9], add(18)(q21)[5],+19[5], add(19)(p11)[9], add (19)(q13)[8],del(19)(p13)[9],+20[7], add(20)(p11)[7],a dd(20)(p13)[8], add(20)(q11)[4],+21[8],+21[4], add(21) (p11)[10], add(21)(p11)[4], add(21)(q22)[7],+22[10],+2 2[7],+22[3], del(22)(q13)[10],del(22)[9],+10 18 mar.

\section{Array CGH}

Significant gains of DNA sequences were observed for locus DAB2 at chromosome 5q13, CCND2 at $12 \mathrm{p} 13$, MDM2 at 12q14.3-q15, FLI, TOP3A at 17p11.2-p12, and OCRL1 at Xq25. Significant losses of DNA sequences were observed for HTR1B at 6q13, D6S268 at 6q16.3-q21, SHGC17327 at 18ptel, and STK6 at 20q13.2-q13.3. The representative aCGH profile is shown in Figure 9.

\section{Discussion}

There have been several reports describing xenotransplantation models of human OS [4-7]. In the present study, the parent tumor, the cultured tumor cells, and the xenografted tumor exhibited features typical of OS, as

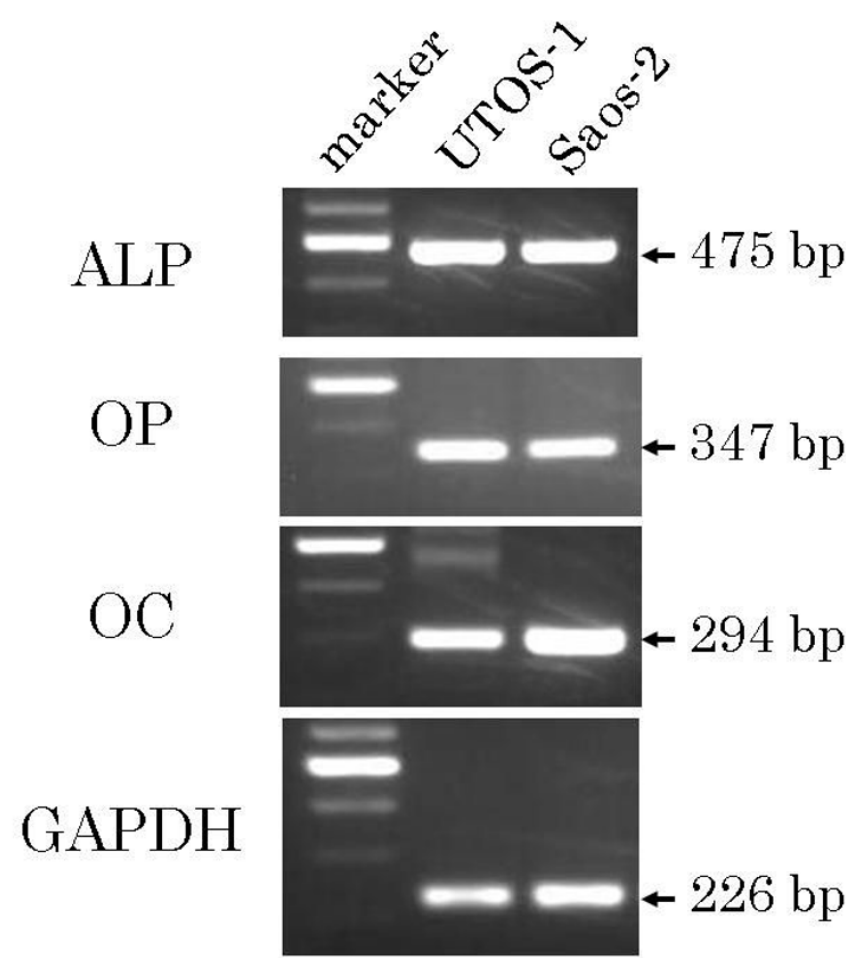

Figure 7

Osteoblast marker expression in UTOS-I cells. The expression of several osteoblast markers, including ALP, OP and OC, is shown. Saos-2, which is one of the most popular OS cell lines, is used as a positive control for osteoblastic markers in UTOS-I cells. These cells express ALP, OP and OC, which is similar to Saoa-2.

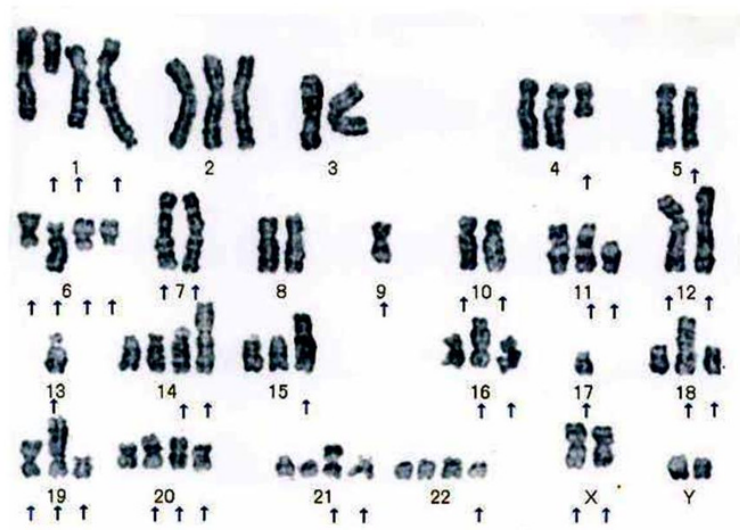

\section{:}

Figure 8

A representative G-banded karyotype of a UTOS-I cell. Arrows show the abnormal chromosomes. 
reported previously $[15,17]$. Cultured UTOS-1 cells have a spindle shape with several nucleoli, which is similar to the original tumor cells. Biochemical characteristics of UTOS1 , such as cell growth rate and osteoblastic activity, have not changed during the 2 years that they have been maintained. Immunohistochemically, the UTOS-1 cells remain positive for ALP, OP and OC. After implantation from cell culture into SCID mice, UTOS-1 cells grew in vivo, producing osteoid resembling that of the original tumor. Abundant osteoid tissue formed in the xenografted tumors and reimplanted tumors. These findings suggest that UTOS-1 cells have an osteoblastic phenotype and retain the characteristics of the original tumor. The population-doubling time of UTOS- 1 cells in vitro is 40 hours, which is similar to that of other OS cell lines $[4,6,18]$.

Several reports indicate that OS cells have karyotypes with multiple numerical rearrangements and complex structural rearrangements [9,19-21]. Together, the results of several cytogenetic surveys indicate that OS cells frequently have structural alterations at chromosome bands 1p11-13, 1q11-12, 1q21-22, 11p15, 12p13, 17p11-3, $19 q 13$, and 22q11-13, and frequently have the numerical chromosome abnormalities $+1,-9,-10,-13$, and -17 . In UTOS- 1 cells, the clonal chromosomal abnormalities that were detected were triploidies. The chromosomal rearrangements that were observed in UTOS-1 involved chromosomes 1q11-12, 11p15, 19q13, and 22q11-13. The numerical chromosome abnormalities that were observed in UTOS- 1 included $+1,-9,-10,-13$, and -17 . These findings are similar to studies of other OS cell lines [8].

Metaphase CGH studies of OS have identified frequent gains at chromosome bands 1p32, 1q21, 5p13, 6p12, 8q24, 8cen-q13, 17p11.2, and Xp21, and frequent losses at bands 6q16, 10p12pter, and 10q22-q26 [22,23]. Recent metaphase CGH studies of OS have focused on amplifications at chromosomes 8q, 6p, and 17p [22,24]. Advances in mapping resolution of microarray CGH

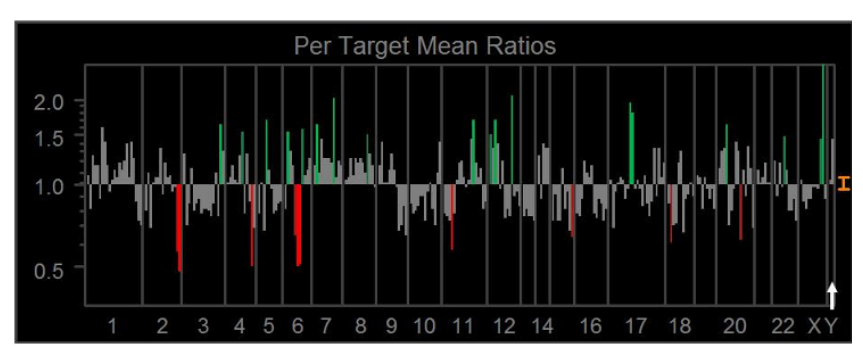

Figure 9

Genetic instability analyzed by aCGH. The line in the middle (gray) is the baseline ratio (I.0); The upper (red) and lower (green) bars in each frame indicate losses and gains, respectively. The arrow shows the axes of $X$ and $Y$ chromosomes.
$[25,26]$ have greatly improved its resolving power, such that it now provides greater detail than metaphase CGH regarding the complexity and exact location of genomic rearrangements leading to copy number imbalances.

In the present study, chromosome 12 showed several distinct regions of focal amplification, occurring at gains of CCND2 at 12p13 12q13 and MDM2 at 12q14.3-q15. Previous CGH studies of OS have revealed abnormalities of chromosome 12, including gains at bands 12p12-p13 [24], 12q12-q13 [27], and 12q13-q14 [28]. Expression of the CCND2 gene, which is located at chromosome $12 \mathrm{p} 13$, has been observed in various malignancies, including prostate cancer and breast cancer [29-31]. CCND2 encodes a protein belonging to the cyclin family of proteins that regulate cyclin-dependent kinase (CDK) kinases [32]. CDK activity controls the cell cycle G1/S transition by regulating phosphorylation of the tumor suppressor protein $\mathrm{Rb}$ [33]. These facts suggest that CCND2 controls proliferation of UTOS-1 tumor cells.

Some studies indicate that 14 to $27 \%$ of OS tumors have abnormal MDM2 expression [34,35]. MDM2 is a target gene of the transcription factor tumor protein p53 [36]. The encoded protein is a nuclear phosphoprotein that binds and inhibits transactivation by tumor protein p53, as part of an autoregulatory negative feedback loop $[37,38]$. Overexpression of MDM2 gene can result in excessive inactivation of tumor protein p53, diminishing its tumor suppressor function. These findings suggest the possible involvement of the p53 tumor suppressor gene, which is associated with development of OS in UTOS-1 cells.

The gain of chromosome band at 17p11.2-p12 has been observed in approximately 13 to $29 \%$ of high-grade OS $[24,39,40]$. In UTOS-1 cells, gain of the genes FLI and TOP3A at chromosome 17p11.2-p12 has been observed. These findings suggest that multiple gains, including FLI, TOP3 or other genes close to these candidate oncogenes, are present at chromosome 17p11.2-p12 and contribute to OS tumorigenesis [41]. Recent studies indicate that overexpression of 17 p11.2-p12 is associated with p53 degradation [42-44].

In a study of OS using a cDNA array, Squire et al. observed amplification of the genes MYC, GAS7, and PM1 in OS cells [45]. Other reports indicate that losses of chromosome bands 6q16 and 6q21-q22 occur in high-grade OS [46]. These findings and those of the present study suggest that gene losses on chromosome 6q, including HTR1B and D6S268, contribute to OS tumorigenesis.

One of the most remarkable breakpoint clusters that have been found in OS tumors was detected on chromosome 
20 by spectral karyotyping (SKY) analysis [47]. Chromosome 20 is one of the smaller chromosomes, suggesting that it is particularly vulnerable to structural rearrangement. However, there is little evidence that chromosome 20 is frequently involved in chromosomal imbalances $[26,28]$. In the present study, the only loss that involved chromosome 20 occurred at band 20q13.2-q13.3. Many chromosomal changes have been observed in CGH studies of high-grade OS [46]. Reports indicate that the genes involved in OS tumorigenesis include DAB2 (at chromosome 5q13), OCRL1 (at Xq25), and SHGC17327 (at 18ptel). However, many of these genes were not previously known to be associated with OS tumorigenesis.

In conclusion, we have isolated and characterized a new permanent human cell line, UTOS-1, established from an osteoblastic OS. This cell line retains the morphology, osteoblastic activities and cytogenetic characteristics of the original tumor in vitro. The UTOS-1 cell line is useful for biologic and molecular pathogenetic studies of human OS.

\section{Competing interests}

The authors declare that they have no competing interests.

\section{Authors' contributions}

Authors have made substantial contributions to conception and design MK and TY acquisition of data. SN, TH, $\mathrm{TO}$ and KS analysis, interpretation of data, organizing study. TY and supervision of research group TK

\section{Acknowledgements}

We thank all members of the Department of Orthopaedic Surgery, University of Toyama.

\section{References}

I. Meyers PA, Gorlick R, Heller G, Casper E, Lane J, Huvos AG, Healey $\mathrm{JH}$ : Intensification of preoperative chemotherapy for osteogenic sarcoma: results of the Memorial Sloan-Kettering (TI2) protocol. J Clin Oncol 1998, 16:2452-2458.

2. Bacci G, Lari S: Current treatment of high grade osteosarcoma of the extremity: review. J Chemother 200I, 13:235-243.

3. Uchida A, Myoui A, Araki N, Yoshikawa H, Shinto Y, Ueda T: Neoadjuvant chemotherapy for pediatric osteosarcoma patients. Cancer 1997, 79:4II-4I5.

4. Fournier B, Price PA: Characterization of a new human osteosarcoma cell line OHS-4. J Cell Biol I99|, I I 4:577-583.

5. Yamane T: Establishment and characterization of cell lines derived from a human osteosarcoma. Clin Orthop 1985, 199:26I-27I.

6. Yoshikawa H, Ohishi M, Kohriki S, Yoshiura M, Ohsaki Y: Establishment and characterization of an osteoblastic clonal cell line from human mandibular osteosarcoma (HMOS-I). Oral Oncol 1997, 33:163-168.

7. Rodan SB, Imai Y, Thiede MA, Wesolowski G, Thompson D, BarShavit Z, Shull S, Mann K, Rodan GA: Characterization of a human osteosarcoma cell line (Saos-2) with osteoblastic properties. Cancer Res 1987, 47:496I-4966.

8. Boehm AK, Squire JA, Bayani J, Nelson M, Neff J, Bridge JA: Cytogenetic findings in $\mathbf{3 5}$ osteosarcoma specimens and a review of the literature. Pediatr Pathol Mol Med 2000, 19:359-376.

9. Ozaki T, Neumann T, Wai D, Schäfer $K L$, van Valen $F$, Lindner $N$, Scheel C, Böcker W, Winkelmann W, Dockhorn-Dworniczak B,
Horst J, Poremba C: Chromosomal alterations in osteosarcoma cell lines revealed by comparative genomic hybridization and multicolor karyotyping. Cancer Genet Cytogenet 2003, I40: I45-I52.

10. Cherrier B, Gouin F, Heymann MF, Thiéry JP, Rédini F, Heymann D, Duteille $F$ : A new experimental rat model of osteosarcoma established by intrafemoral tumor cell inoculation, useful for biology and therapy investigations. Tumor Biol 2005, 26:121-130.

II. Yasuda T, Matsui H, Kanamori M, Yudoh K, Ohmori K, Aoki M, Tsuji $\mathrm{H}$ : Effects of tumor cell-derived interleukin I alpha on invasiveness of metastatic clones of murine RCT sarcoma through endothelial cells. Tumor Biol 1999, 20:105-II6.

12. Carmichael J, DeGraff WG, Gazdar AF: Evaluation of a tetrazolium-based semiautomated colorimetric assay: assessment of chemosensitivity testing. Cancer Res 1987, 47:936-942.

13. Koide O, Iwai S, Kanno T, Kanda S: Isoenzyme of alkaline phosphatase in germinoma cells. Am J Clin Pathol 1988, 89:6I I-6I6.

14. Nishio J, Iwasaki H, Ishiguro M, Ohjimi $Y$, Yo S, Isayama T, Naito M, Kikuchi M: Supernumerary ring chromosome in a Bednar tumor (pigmented dermatofibrosarcoma protuberans) is composed of interspersed sequences from chromosomes 17 and 22: a fluorescence in situ hybridization and comparative genomic hybridization analysis. Genes Chromosomes Cancer 200I, 30:305-309.

15. Shaffer LG, Tommerup N, editors: ISCN. An international system for human cytogenetic Nomenclature. Basel: S Karger 2005.

16. Kallioniemi A, Kallioniemi OP, Sudar D, Rutovitz D, Gray JW, Waldman F, Pinkel D: Comparative genomic hybridization for molecular cytogenetic analysis of solid tumors. Science 1992, 258:8|8-82I.

17. Bilbe G, Roberts E, Birch M, Evans DB: PCR phenotyping of cytokines, growth factors and their receptors and bone matrix proteins in human osteoblast-like cell lines. Bone 1996, 19:437-445.

18. Rochet N, Dubousset J, Mazeau C, Zanghellini E, Farges MF, de Novion HS, Chompret A, Delpech B, Cattan N, Frenay M, Gioanni J: Establishment, characterization and partial cytokine expression profile of a new human osteosarcoma cell line (CAL 72). Int J Cancer 1999, 82:282-285.

19. Bridge JA, Nelson M, McComb E, McGuire MH, Rosenthal H, Vergara G, Maale GE, Spanier S, Neff JR: Cytogenetic findings in 73 osteosarcoma specimens and a review of the literature. Cancer Genet Cytogenet 1997, 95:74-87.

20. Murata $H$, Kusuzaki K, Takeshita $H$, Hirasawa $Y$, Ashihara T, Abe T, Inazawa J: Aberrations of chromosomes I and I 7 in six human osteosarcoma cell lines using double-target fluorescence in situ hybridization. Cancer Genet Cytogenet I998, 107:7-10.

21. Wolf M, Tarkkanen M, Hulsebos T, Larramendy ML, Forus A, Myklebost $\mathrm{O}$, Aaltonen LA, Elomaa I, Knuutila S: Characterization of the 17p amplicon in human sarcomas: microsatellite marker analysis. Int J Cancer 1999, 82:329-333.

22. Sandberg AA, Bridge JA: Updates on the cytogenetics and molecular genetics of bone and soft tissue tumors: osteosarcoma and related tumors. Cancer Genet Cytogenet 2003, I45: I-30.

23. Overholtzer M, Rao PH, Favis R, Lu XY, Elowitz MB, Barany F, Ladanyi $M$, Gorlick R, Levine AJ: The presence of p53 mutations in human osteosarcomas correlates with high levels of genomic instability. Proc Natl Acad Sci USA 2003, I00: I I547-II 552.

24. Tarkkanen M, Karhu R, Kallioniemi A, Elomaa I, Kivioja $A H$, Nevalainen J, Böhling T, Karaharju E, Hyytinen E, Knuutila S, Kallioniemi OP: Gains and losses of DNA sequences in osteosarcomas by comparative genomic hybridization. Cancer Res 1995, 55:1334-1338.

25. Beheshti B, Braude I, Marrano P, Thorner P, Zielenska M, Squire JA: Chromosomal localization of DNA amplifications in neuroblastoma tumors using cDNA microarray comparative genomic hybridization. Neoplasia 2003, 5:53-62.

26. Pollack JR, Perou CM, Alizadeh AA, Eisen MB, Pergamenschikov A, Williams CF, Jeffrey SS, Botstein D, Brown PO: Genome-wide analysis of DNA copy-number changes using CDNA microarrays. Nat Genet 1999, 23:41-46. 
27. Hulsebos T], Biileveld EH, Oskam NT, Westerveld A, Leenstra S, Hogendoorn PC, Bras J: Malignant astrocytoma-derived region of common amplification in chromosomal band $17 \mathrm{p} / 2$ is frequently amplified in high-grade osteosarcomas. Genes Chromosomes Cancer 1997, 18:279-285.

28. Tarkkanen M, Böhling T, Gamberi G, Ragazzini P, Benassi MS, Kivioja A, Kallio P, Elomaa I, Picci P, Knuutila S: Comparative genomic hybridization of low-grade central osteosarcoma. Mod Pathol 1998, I I:421-426.

29. Knuutila S, Autio K, Aalto Y: Online access to CGH data of DNA sequence copy number changes. Am J Pathol 2000, I 57:689.

30. Padar A, Sathyanarayana UG, Suzuki M, Maruyama R, Hsieh JT, Frenkel EP, Minna JD, Gazdar AF: Inactivation of cyclin D2 gene in prostate cancers by aberrant promoter methylation. Clin Cancer Res 2003, 9:4730-4734.

3I. Yu J, Leung WK, Ebert MP, Leong RW, Tse PC, Chan MW, Bai AH, To KF, Malfertheiner P, Sung J]: Absence of cyclin D2 expression is associated with promoter hypermethylation in gastric cancer. BrJ Cancer 2003, 88: I560- I565.

32. Morgan DO: Principles of Cdk regulation. Nature 1995, 374: $13|-| 34$.

33. Weinberg RA: The retinoblastoma protein and cell cycle control. Cell 1995, 8I:323-330.

34. Ladanyi M, Cha C, Lewis R, Jhanwar SC, Huvos AG, Healey JH: MDM2 gene amplification in metastatic osteosarcoma. Cancer Res 1993, 53:16-18.

35. Oliner JD, Kinzler KW, Meltzer PS, George DL, Vogelstein B: Amplification of a gene encoding a p53-associated protein in human sarcomas. Nature 1992, 358:80-83.

36. Sakamuro D, Sabbatini P, White E, Prendergast GC: The polyproline region of p53 is required to activate apoptosis but not growth arrest. Oncogene 1997, 15:887-898.

37. Kubbutat MH, Jones SN, Vousden KH: Regulation of p53 stability by Mdm2. Nature 1997, 387:299-303.

38. Candau R, Scolnick DM, Darpino P, Ying CY, Halazonetis TD, Berger SL: Two tandem and independent sub-activation domains in the amino terminus of $\mathrm{p} 53$ require the adaptor complex for activity. Oncogene 1997, 15:807-816.

39. Stock C, Kager L, Fink FM, Gadner H, Ambros PF: Chromosomal regions involved in the pathogenesis of osteosarcomas. Genes Chromosomes Cancer 2000, 28:329-336.

40. Zielenska M, Bayani J, Pandita A, Toledo S, Marrano P, Andrade J, Petrilli A, Thorner P, Sorensen P, Squire JA: Comparative genomic hybridization analysis identifies gains of Ip35-36 and chromosome 19 in osteosarcoma. Cancer Genet Cytogenet 200I, 130:14-2|.

4I. van Dartel M, Cornelissen PW, Redeker S, Tarkkanen M, Knuutila S, Hogendoorn PC, Westerveld A, Gomes I, Bras J, Hulsebos TJ: Amplification of $17 \mathrm{pl} 1.2-\mathrm{p} 12$, including PMP22, TOP3A, and MAPK7 in high-grade osteosarcoma. Cancer Genet Cytogenet 2002, 139:91-96.

42. van Dartel M, Redeker S, Bras J, Kool M, Hulsebos TJ: Overexpression through amplification of genes in chromosome region I7p||.2-p/2 in high-grade osteosarcoma. Cancer Genet Cytogenet 2004, 152:8-14.

43. Henriksen J, Aagesen TH, Maelandsmo GM, Lothe RA, Myklebost $O$, Forus A: Amplification and overexpression of COPS3 in osteosarcomas potentially target TP53 for proteasome-mediated degradation. Oncogene 2003, 22:5358-536I.

44. van Dartel M, Hulsebos TJ: Amplification and overexpression of genes in 17pII.2-pI 2 in osteosarcoma. Cancer Genet Cytogenet 2004, 1 53:77-80.

45. Squire JA, Pei J, Marrano P, Beheshti B, Bayani J, Lim G, Moldovan L, Zielenska M: High-resolution mapping of amplifications and deletions in pediatric osteosarcoma by use of CGH analysis of cDNA microarrays. Genes Chromosomes Cancer 2003, 38:215-225

46. Tarkkanen M, Elomaa I, Blomqvist C, Kivioja AH, KellokumpuLehtinen P, Böhling T, Valle J, Knuutila S: DNA sequence copy number increase at $8 \mathrm{q}$ : a potential new prognostic marker in high-grade osteosarcoma. Int J Cancer 1999, 84: I |4-I2I.

47. Bayani J, Zielenska M, Pandita A, Al-Romaih K, Karaskova J, Harrison K, Bridge JA, Sorensen P, Thorner P, Squire JA: Spectral karyotyping identifies recurrent complex rearrangements of chromosomes 8, 17, and 20 in osteosarcomas. Genes Chromosomes Cancer 2003, 36:7-16.
Publish with Biomed Central and every scientist can read your work free of charge

"BioMed Central will be the most significant development for disseminating the results of biomedical research in our lifetime. "

Sir Paul Nurse, Cancer Research UK

Your research papers will be:

- available free of charge to the entire biomedical community

- peer reviewed and published immediately upon acceptance

- cited in PubMed and archived on PubMed Central

- yours - you keep the copyright

Submit your manuscript here:

http://www.biomedcentral.com/info/publishing_adv.asp
BioMedcentral 